\title{
Measuring the True Potential of Lifestyle Brands in India: A Consumer-Level Scale for Existing and Potential Investors(CL-LBSi)
}

\author{
H. R. Ganesha ${ }^{1}, \&$ P. S. Aithal ${ }^{2}$ \\ ${ }^{1}$ Chief Executive Officer - Consulting Division, Gramss Retail Trading Private Limited, \\ Bengaluru - 560078, India and Post-Doctoral Research Fellow, College of Management \& \\ Commerce, Srinivas University, Mangalore - 575001, India. \\ OrcidID: 0000-0002-5878-8844; E-mail: hrganesha@yahoo.co.in \\ ${ }^{2}$ Vice Chancellor, Srinivas University, Mangalore - 575001, India. \\ OrcidID: 0000-0002-4691-8736; E-mail: psaithal@gmail.com
}

Area of the Paper: Business Management.

Type of the Paper: Research Paper.

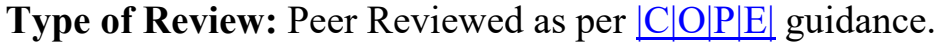

Indexed In: OpenAIRE.

DOI: http://doi.org/10.5281/zenodo.3940586.

Google Scholar Citation: IJCSBE.

\section{How to Cite this Paper:}

Ganesha, H. R., Aithal, P. S. (2020). Measuring the True Potential of Lifestyle Brands in India: A Consumer-Level Scale for Existing and Potential Investors(CL-LBSi). International Journal of Case Studies in Business, IT, and Education (IJCSBE), 4(1), 207-222.

DOI: http://doi.org/10.5281/zenodo.3940586.

International Journal of Case Studies in Business, IT and Education (IJCSBE) A Refereed International Journal of Srinivas University, India.

(C) With Authors.

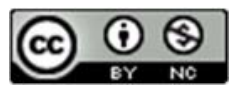

This work is licensed under a Creative Commons Attribution Non-Commercial 4.0 International License subject to proper citation to the publication source of the work.

Disclaimer: The scholarly papers as reviewed and published by the Srinivas Publications (S.P.), India are the views and opinions of their respective authors and are not the views or opinions of the S.P. The S.P. disclaims of any harm or loss caused due to the published content to any party. 


\title{
Measuring the True Potential of Lifestyle Brands in India: A Consumer-Level Scale for Existing and Potential Investors(CL-LBSi)
}

\author{
H. R. Ganesha ${ }^{1}$, \& P. S. Aithal ${ }^{2}$ \\ ${ }^{1}$ Chief Executive Officer - Consulting Division, Gramss Retail Trading Private Limited, \\ Bengaluru - 560078, India and Post-Doctoral Research Fellow, College of Management \& \\ Commerce, Srinivas University, Mangalore - 575001, India. \\ OrcidID: 0000-0002-5878-8844; E-mail: hrganesha@yahoo.co.in \\ ${ }^{2}$ Vice Chancellor, Srinivas University, Mangalore - 575001, India. \\ OrcidID: 0000-0002-4691-8736; E-mail: psaithal@gmail.com
}

\begin{abstract}
It is evident that among more than 5000 Indian lifestyle brands, only a few brands have created true lifestyle brand image in their employees, investors, competitors, and consumer's minds, and the trueness level of a majority of Indian lifestyle brands is still in question. The majority of developing and developed Indian lifestyle brands assume that the success of a lifestyle brand is measured basis the revenue or profit they generate and are unaware of implicit long-term strategical benefits of creating a true lifestyle brand image in consumer's minds. In India, the lifestyle category has also become one of the most sought-after categories for many start-up entrepreneurs. Just because there is an evident gap for a certain lifestyle product category in the market and just attempting to fill such a gap does not guarantee sustainable success. India indeed is one of the countries with consumers belonging to the widest range of Religions, Regions, Languages, Sub-Cultures and Economic backgrounds which makes it very difficult for any lifestyle brand to own a true lifestyle brand image at National level and makes it furthermore important for them to be more careful and efficient in ensuring adaptation of right consumer-level evaluation techniques and tools to regularly measure a brand's the true potential in attaining a sustainable profitable stage of its evolution. Both new and existing lifestyle brands in India inevitably require investors to fund their journey of attaining the final stage of evolution which is known as a sustainable profitable stage. However, in the absence of any inputs-driven consumer-level measurement instruments, investors are in a quandary to gauge, estimate and forecast the true potential of lifestyle brands in India from the consumer point of view before they make any investment decisions and usually most of the investors follow traditional brand equity or valuation methods which are mostly skewed toward outputdriven measures and sometimes they are misleading. In this exhaustive empirical study, we have studied a few select lifestyle brands, investors and investments to identify 68inputs-based sub-elements across 4 key elements and 3 dimensions to design a simple consumer-level instrument named as CL-LBSi, which would measure the true potential of a lifestyle brand in India irrespective of the brand's current age in the Indian retail market.
\end{abstract}

Keywords: Indian Retail, National Brand, Lifestyle Brand Image, Indian Lifestyle Brand, Brand Equity, Brand Value, Brand Scale, Investors, Start-Up Brands, Investor Scale, Consumer-Level Scale, CL-LBSi, Investment Decision Framework.

\section{INTRODUCTION :}

Despite various issues faced by existing and potential investors in measuring and evaluating the true potential of lifestyle brands in India to gain the true lifestyle brand image among employees, investors, competitors, and consumer's minds, many start-ups and established lifestyle brands of Indian origin 
have attracted investors. To name a few, i) Biba; ii) W for Women; iii) AND; iv) Kaaryah; v) Faballey; vi) Zink London; and vii) Stock Buy Love. We have observed that a) many investors and investments in Indian lifestyle brands have gone through a learning curve over last five years, ii) investors are trying to find better ways to evaluate the true potential of Indian lifestyle brands, c) the majority of investments are attracted by lifestyle brands whose business model is predominantly skewed toward online retailing and, d) month-on-month revenue growth is given more preference over unit economics of these brands. The majority of the investors are considering few key factors while determining the decision to invest especially in new/start-up lifestyle brands such as a) gap in the market, b) original concept/idea, c) short-term and long-term motives of the founders, and d) academic/industry affiliations of the founders.

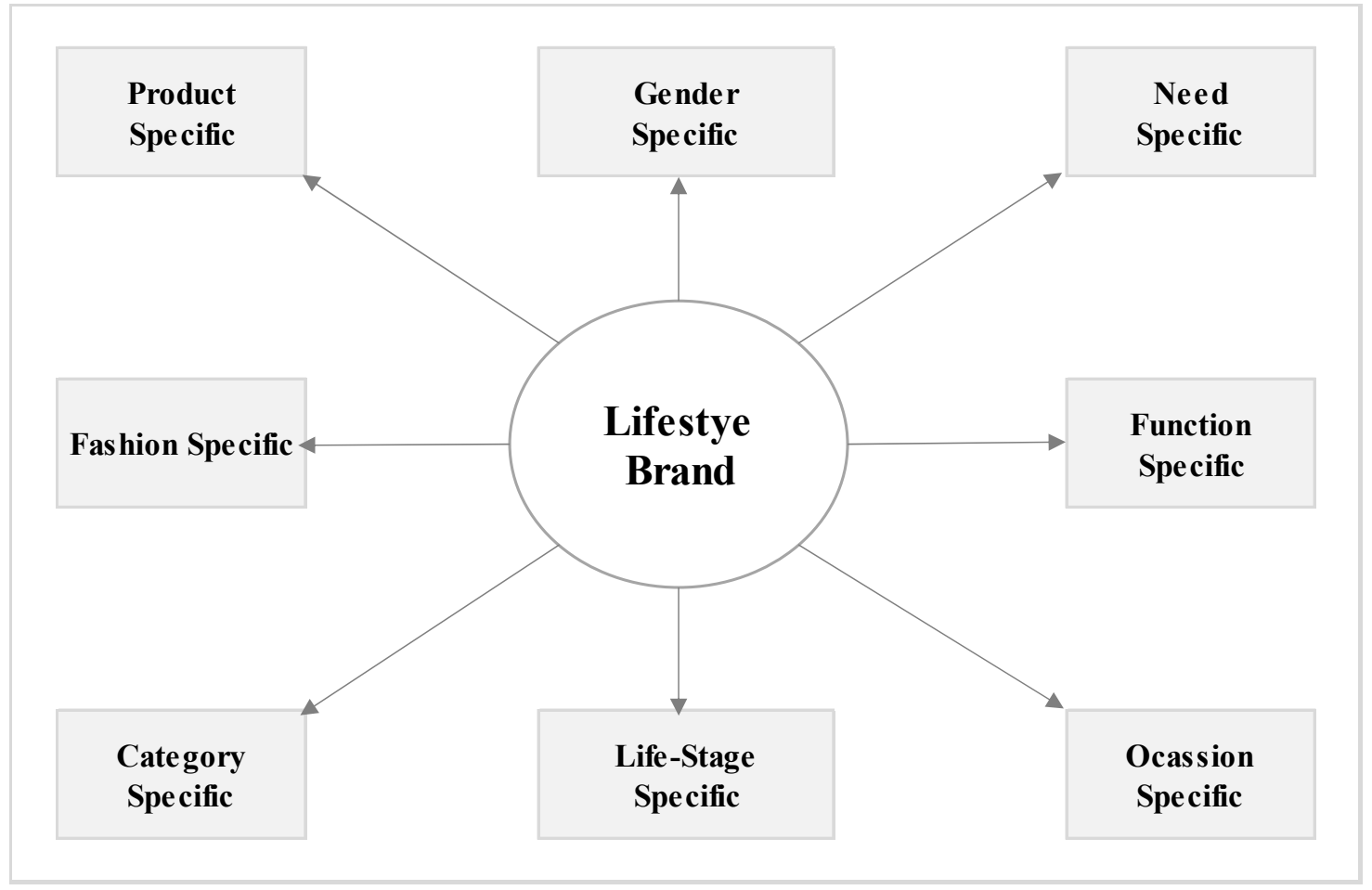

Fig. 1: Product offerings by lifestyle brands in India [59]

Each individual wants to have a unique identity that could be based on his/her, a) background such as nationality, ethnicity, culture, subculture, social class, affiliation, environment, etc; b) experiences and c) choices. Lifestyle brands attempt to evoke emotional connections between consumers and they need to have a unique identity and most importantly lifestyle brands are increasingly becoming one of the key components of consumer's self-expression [1]. To ensure the scope of this study is focussed, we define lifestyle brands as the ones, which attempt to offer a complete solution for a specific or wider lifestyle needs of consumers through their products such as Apparel, Footwear, and Accessories with an ultimate goal of their products being key contributors of an implicit or explicit statement of consumers personality and identity. Lifestyle retail market size in India is expected to reach 130 billion USD by the year 2023 which is a 77 percent growth when compared to the year 2013 [2]. Based on India's 2011 census, the United Nation's (UN) Department of Statistics and Program Implementation estimates the Indian population to reach close to 1.38 billion by the year 2020 [3]. It is estimated that more than 300 Global lifestyle brands have plans to open their stores in India this year [4]. In addition to this humongous population, exponential growth in several working women, double-income families, middle-class consumer segment, increasing disposable income, rapid adoption of fashion, urbanization, the overall size of Indian retail industry, more and more unorganized retailers becoming organized, the emergence of modern retailing formats and a most importantly enormous increase in 
internet penetration/usage, simply caution existing and upcoming lifestyle brands and investors to revisit their existing brand performance evaluation techniques and tools.

Owing to the sheer market size and potential, India has attracted many global lifestyle brands. A few Global brands have attempted to offer their product assortment as being a shop-in-shop at select large retail format stores, few have offered their product assortment through having EBOs, few have shown their presence only in the online store and few have licensed their brands to third parties or entered into a Joint Venture to offer their products in Indian retail market. To name a few Levi's, Zara, United Colors of Benetton, Marks \& Spenser, H\&M, Mother Care, Carter's, Puma, Nike, Adidas, Reebok, Armani Exchange, Diesel, Gas, Gap, The Children's Place, Quiksilver, Superdry, Kappa, Bossini, Calvin Klein, Hanes, Tommy Hilfiger, Ed Hardy, Izod, Nautica, Arrow, U.S. Polo Assn, Jack \& Jones, Vero Moda, Tumi, Lee, Hero, Maverick, Wrangler, Fila, and Jockey. Unless these Global lifestyle brands explore sourcing their products predominantly from India, competitive pricing remains one of the key challenges as far as their sustainable success in the Indian market is concerned. The country also has a vast number of lifestyle brands that originated from India. One can list more than 5000 lifestyle brands in India [5], of which few of them have a strong presence all over India, few have a strong presence only in certain regions of India and few are available only online. It is evident that, despite such humongous number of lifestyle brands available in India one could list only a few which can be tagged as well-known/familiar/reputed Indian lifestyle brands such as, Biba, Manyavar, Soch, Gini \& Jony, Blackberrys, Louis Phillipe, Peter England, Provogue, Monte Carlo, Mufti, W for Women, Oxemberg, Indian Terrain, Global Desi, Parx, S Kumar's, Vimal, Mini Klub, Aurelia, Sparx, Campus, Go Colors, Enamour, HiDesign, Lino Perros, Idee, Spykar, Killer Jeans, Flying Machine, Da Milano, Park Avenue, Ethnix, ColorPlus, Lux Cozy, WildCraft, 612 League, WLS, John Players, Fastrack, 109 F, Proline, Image, Jealous 21, Liberty, Paragon and few more. Only a few names from the list of more than 5000 brands possibly indicating that despitethe humongous population and the retail market size in India, the majority of Indian lifestyle brands have failed to establish themselves as true lifestyle brands. We attribute this failure majorly to the Marketing Mix being adopted by these brands in addition to their poor understanding of the true lifestyle brand image. Figure 1 depicts the product offering of typical lifestyle brands in India. Dominantly the majority of lifestyle brands in India offer just one of these and very few caters to multiple products offering to multiple consumer groups.

\section{LITERATURE REVIEW :}

Brand Equity: It is important for the marketer to constantly work on strategies to convert the existing brand image into equity [6]. Few researchers have investigated the correlation among the competition of brands, the formation of consumers' attitudes, and intention to choose a particular brand or alternatives being offered to the consumers at a given point of time and the place of the offering. The findings of these studies confirm firm that consumers' evaluations, understandings, and knowledge about a particular brand of their choice are not just the key influences of creating intentions of buying a product belonging to a brand, it is also consumers' perspectives and perceptions toward another alternative or brand available in the offering [7]. There are few brands which have gained strong brand equity owing to consumers having a special, favourable association with such brands in their memories and these brands were able to create higher perceived quality, awareness about the brand name and ultimately leading huge loyal consumers over a period and brand image, though being a qualitative aspect of a brand, plays an important role in overall brand equity as far as consumer perspective is concerned. Brand image is one of the most important concepts in addition to brand associations, loyalty, awareness, and product quality of a brand concerning the consumers' utility and brand equity is concerned [8 - 10]. Consumers tend to correlate their personality with the brand personality they are willing to associate with, wherein they attribute this to their demographic characteristics, physical characteristics, personality traits and, cognitive abilities consequently leading them to buy a brand's product to implicitly or explicitly express/showcase their image or identity [11 - 12]. In one of the studies conducted twenty years back in a developed country to understand as to why consumers are willing to purchase products of National brands over Store brands even though the products of National brands were priced at least 20 percent higher than products of Store brands, it was found that the brand equity was the key variable which leads to this willingness [13]. In addition to basic five concepts suggested by 'Aaker' in the year 1991, which could impact the brand equity and image viz., i) Brand 
Awareness; ii) Brand Associations; iii) Perceived Quality; iv) Brand Loyalty; and v) Other Proprietary Brand Assets [10], huge number of research studies have been carried out to understand different factors which can impact brand equity, such as, co-branding or jointly branded products [14]; meaning transfer and celebrity endorsement [15]; perceived service quality [16]; advertising and marketing events [17]; perceived attractiveness [18]; effective communication, new product development, and distribution [19]; brand knowledge [20]; corporate brand image [21]; effective brand management [22]; family-based brand system [23]; represented group identity, reconciled self-image and targeted brand positioning [24 - 25]; charity activities of brands [26]; consumers' experiences [27]; brand personality [28]; brand heuristic [29]; brand magic [30]; brand attributes [31]; brand attitude [32]; brand description [33]; brand name awareness [34]; brand meaning [35]; brand trust [36]; brand name [37]; brand community [38]; brand attachment [39]; brand love [40]; brand experience [41]; product experiences [42]; shopping experiences [43]; service experiences [44]; consumption experiences [45]; brand credit [46]; the brand's country of origin [47]; brand authenticity [48]; long-run competitive advantage [4950]; contribution of branding to the physical product [51]; brand extension [52]; and, consumer created visual content [53]. It is imperative to understand the existing literature, theories, models and frameworks on retailing across formats, as a significant proportion of lifestyle the brand's success in establishing itself as a true lifestyle brand in the consumers' mind is moderated by the brand's and consumers' choice of retailing format also. Retailing in India has gone through many stages of evolution such as liberalization, organized retailing, globalization, digitalization, and urbanization. Retailing in India was and is heavily driven by unorganized retailers and the same is evident by the sheer market share it owns even today despite Indian retailing have had gone through various stages of evolution. Various studies report a favourable and improving market share for organized retailers. Organized retailing in India is expected to have approximately 25 percent of the market share by the year 2021 which was at 12 percent in the year 2017 [54]. We believe that the unorganized retailers also have evolved over a while in modifying their Marketing Mix to adopt changing consumer mindset and growing competition from organized retailers, thus one can attribute the slow penetration of organized retailing in India to this open mind-set of unorganized retailers to constantly work on their Marketing Mix in addition to their understanding of unit economics of the brand which is the key brand performance methodology they have adopted irrespective of impulse changes in the market environment. In turn, this becomes a classic example of considerable magnitude to confirm firmly that the "4P's" framework of McCarthy which was conceptualized sixty years ago holds even today in India. One could argue that, if unorganized retailers begin to turn into even semi-organized retailers, then it poses significant challenges to organized retailers in India to cope up with unorganized retailers. It is inevitable for organized retailers to keenly focus on their Marketing Mix strategies and strive to create differentiation across various elements of Marketing Mix and use them as part of their brand performance evaluation methods.

Brand Evaluation: Various studies have attempted to develop different brand performance and evaluation tools and techniques both at the firm and consumer levels across many different attributes of a brand. To name a few, a) Brand Equity; b) Brand Loyalty; c) Brand Value; d) Brand Image; d) Marketing Mix Adoptability; e) Strategy Adoptability; f) Brand Experience; g) Brand Experience; h) Brand Disloyalty; i) Brand Personality; j) Brand Authenticity; k) Brand Management; 1) Brand Communication; m) Brand Positioning; n) Brand Attachment; o) Brand Love; p) Brand Extension; q) The brand's Perceived Product Quality; r) Brand Awareness; s) Brand Relevance; t) Brand accessibility; u) The brand's Emotional Connections; v) The brand's Consumer Life-Time Value; w) The brand's Rate of Sustained Growth; $x$ ) The brand's Loyalty Programs; y) The brand's Consumer Acquisition Rates; and z) The brand's Market Share. We have observed that the majority of these techniques to measure a brand's performance are 'output-measure-driven' and focus on any one of the attributes such as i) Financial Metrics; ii) Marketing Assets Metrics; iii) Perception Metrics; and, iv) Competitive Metrics. We believe that Lavidge and Steiner's original 'hierarchy of effects model' conceptualized during the $1960 \mathrm{~s}$, that the consumers' journey of purchase decision begins with 'Awareness', flows through 'Knowledge', 'Liking', 'Preference', 'Conviction', and ends with a 'Purchase' [55], which was later used in the consumer loyalty studies whereby researchers extended this six-stage model further by adding two more elements such as 'Repeat Purchase' and 'Referring the brand/product/service to others post-Purchase' which would possibly help in building the brand 
image. This models and framework are still relevant in the Indian context, and we intend to use basic principles of these theories in this study in addition to the basic "4P's" Marketing Mix proposition which was originally framed by McCarthy sixty years ago [56], therefore we intend to give utmost priority to the basic elements of original " $4 \mathrm{P}$ 's Marketing Mix framework to develop a consumer-level scale which would help existing and potential investors to measure the true potential of lifestyle brands in India irrespective of the brand's evolution stage and age in the Indian retail market thereby enabling them to make a rational decision while investing.

The need for this research indeed was originated due to various gaps found in theoretical, descriptive, empirical literature available in the brand performance measurement and evaluation domain such as a) the majority of studies have focussed on specific brand attributes and predominantly skewed toward output/perception driven measurements; b) the majority of studies have focussed on brands in general and not specific to lifestyle brands; c) absence of inputs-driven consumer-level brand performance and evaluation instruments for a lifestyle brand in the Indian context; d) a majority of lifestyle brands in India follow and practice evaluation techniques incorporated by consumer goods and other generalist brands; and, most importantly; e) many investors are constantly approached by start-ups and established lifestyle brands of Indian origin to obtain funds. Thus, we decided to carry out an exhaustive empirical study to design a consumer-level scale which is predominantly built on inputs-driven measures and can measure the trueness level of lifestyle brands image in India thereby enabling existing and potential investors to measure/evaluate the true potential of a lifestyle brand in India to gain the true lifestyle brand image among potential and existing employees, investors, competitors, and consumers' mind.

\section{OBJECTIVES :}

Key objectives of this research were to, i) understand lifestyle brands market in India; ii) understand evolution and performance of Indian lifestyle brands; iii) understand the key advantages of gaining a lifestyle brand image across employees, investors, competitors, and consumers' mind; iv) understand existing measures and evaluation techniques to estimate the true potential of lifestyle brands in India; iv) analyze recommendations from previous research studies; v) develop a the consumer-level scale to measure and evaluate the true potential of lifestyle brands India; and vi) recommend appropriate methodology to use the scale.

\section{METHODOLOGY :}

Secondary Research: Intense and in-depth analysis of data available in the public domain was carried to collect data relating to various aspects of lifestyle brands in India through company websites, company annual financial reports, investment patterns, investors, Government database, trade, and business journals. Research works relating to Indian lifestyle brands were surveyed extensively to collect insights, recommendations, and frameworks to measure and evaluate the true potential of lifestyle brands in India.

Quantitative Primary Research: In the first stage, few lifestyle brands in India were selected who can represent, a) different product categories such as fashion; functional, life-stage specific, productspecific, gender-specific, and need-specific products; b) offering single-product category, and multiple-product categories; c) serving different consumer target groups at low, mid-low, mid, midhigh, high, and premium price positioning; d)selling their products through local retailers either directly or using distributors, regional retailers either directly or using distributors, national retailers, exclusive brand outlets (EBO) operated directly by the brand, EBOs operated by a franchisee, online EBO storeoperated either directly or using third parties and, online marketplaces; e) products manufactured from own factory, contract manufacturers both inside and outside India; f) across developing brands, developed brands, and, established brands. In the second stage, data were collected from these select lifestyle brands to design the scale. We have evaluated recommendations and suggestions of our previous empirical research studies concerning lifestyle brands in India to design and develop the consumer-level instrument to measure the true potential of lifestyle brands in India by existing and potential investors [57 - 59]. 


\section{DEVELOPMENT OFCL-LBSi INSTRUMENT :}

Dimensions of CL-LBSi Instrument: Before we head on to explaining the CL-LBSi scale, let us first define the key dimensions of the scale. We determinedly follow the integrated Marketing-Mix framework for lifestyle brands in India that was developed by us in a previous empirical study [55] to derive key dimensions of the CL-LBSi instrument. Three key dimensions that are detrimental for a lifestyle brand's sustainable success in the Indian market are, i) Supply-side; ii) Demand-side, and iii) Connectors of Supply and Demand-side. This is not in any order of preference as one has to understand that it is inevitable for a lifestyle brand to give equal importance to all these three dimensions irrespective of the magnitude of their business and the stage of their evolution. As the CL-LBSi scale is an input-driven instrument it is imperative for us to identify, a) key inputs across all the three dimensions; b) elements and sub-elements of each of these dimensions; c) expected outcome of these elements and sub-elements; d) the single most important output; and most importantly; e) the flow. Figure 2 illustrates the journey of a brand to gain a true lifestyle image in existing and potential employees, investors, competitors, and consumers' minds in a systematic and measurable flow.

Items of CL-LBSi Instrument: The CL-LBSi scale has 3 dimensions, 4 elements, and 68 subelements/items which are defined as below and illustrated in Figure 3.

Supply-Side (S): We believe that Lavidgeand Steiner's original 'hierarchy of effects model' conceptualized during the 1960s, the consumers' journey of purchase decision begins with 'Awareness'. 'Awareness combined with Familiarity' should be given priority in the beginning stages of establishing a true lifestyle brand. Consumer retention rate or consumer loyalty are output in nature whereas 'Awareness' is an input component of the consumer purchase decision-making process. To create brand awareness and familiarity in India brand has to cater to as many consumer groups as possible; and regularly communicate with their target consumers with consistency, accuracy, and authenticity in the communication content that needs to be consumer-centric. We have identified two key elements under this dimension which are, i) creating an all-in-one brand image through wider product offering catering to multiple consumer groups (Sa); and ii) unique and all-needs-fulfillment assortment (Sb). A brand could argue that it will only focus on specific consumer groups and specific product categories as the brand is not comfortable with other available consumer groups and product categories. This argument is weak as far as long-term brand sustainability is concerned in addition to limiting the brand's potential value in addition to weakening the ability to economically optimize on all the promotion and communication efforts. Under the element ' $\mathrm{Sa}$ ' we have identified subelements/items which would be useful in measuring viz., Sa1) consumers grouped as Pregnant and Nursing Women; Sa2) consumers grouped as Babies (0-1 Year); Sa3) consumers grouped as Infants (1 to 3 Years); Sa4) consumers grouped as Kid Boys (2 to 8 Years); Sa5) consumers grouped as Kid Girls (2 to 8 Years); Sa6) consumers grouped as Teen Boys (8 to 16 Years); Sa7) consumers grouped as Teen Girls (8 to 16 Years); Sa8) consumers grouped as Young Women (18 to 30 Years); Sa9) consumers grouped as Young Men (18 to 30 Years); Sa10) consumers grouped as Women (Above 30 Years); Sa11) consumers grouped as Men (Above 30 Years); Sa12) products grouped as Apparel; Sa13) products grouped as Footwear, and Sa14) products grouped as Accessories. As mentioned earlier there are more than 5000 Indian lifestyle brands in addition to well-known global lifestyle brands in India. 


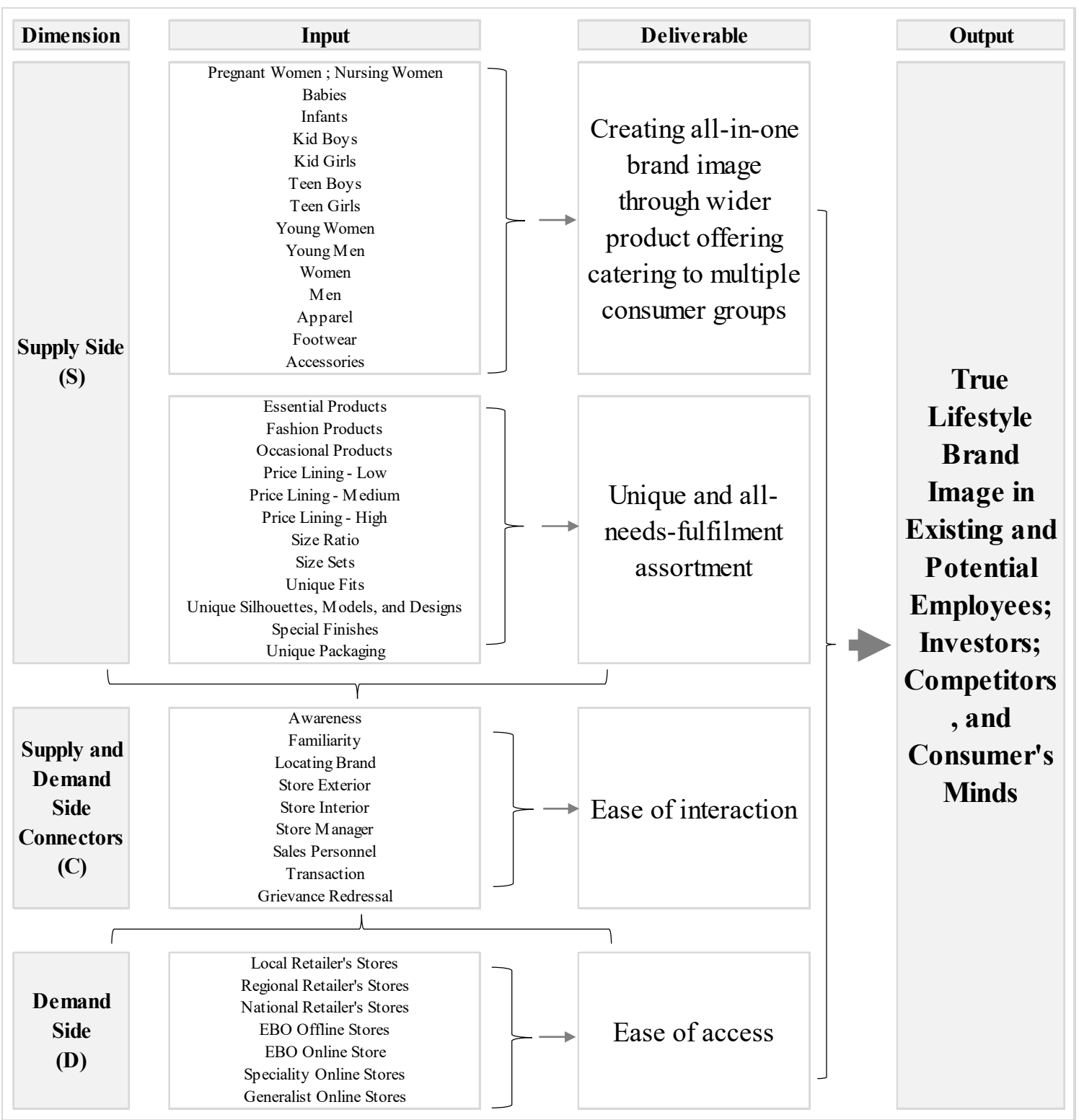

Fig. 2: Inputs to output flow across dimensions of the proposed CL-LBSiScale.

It is universally accepted phenomenon that the 'Product' plays an important role in establishing a 'true lifestyle brand' image in consumers' mind and it is imperative to all the lifestyle brands that, each product tagged with the brand name must be created in such a way it creates positive and unique perceptions in addition to long term memories in consumers' mind. A brand might argue that it is easier to maintain product uniqueness if we manufacture all the components of a finished product using the brand's factory. This argument is not valid as the financials of such model does not support them. Many reputed Global brands do not own any manufacturing facilities, what they own is the designs and creative elements of each component of a finished product through nominated supply chain partners who have been aligned to the brand's tangible and intangible personality and image. Under the second element $(\mathrm{Sb})$ we have identified sub-elements/items which would be useful in measuring viz., Sb1) essential products grouped and displayed together; Sb2) fashion products grouped and displayed together; $\mathrm{Sb} 3$ ) occasional products grouped and displayed together; Sb4) low-price point product range; $\mathrm{Sb5}$ ) medium price-point product range; $\mathrm{Sb6}$ ) high price-point product range; $\mathrm{Sb} 7$ ) appropriate size ratios; Sb8) an appropriate number of size sets; Sb9) fits unique to the brand; Sb10) 
designs unique to the brand; Sb11) special product finishes unique to the brand; Sb12) product packaging unique to the brand. All these sub-elements directly or indirectly help the brand to, i) own and use these unique properties to promote the brand; ii) use them as strong communication contents, and most importantly iii) helps a brand to create unique memories in the consumers' minds across multiple consumer groups.

Demand-Side (D): To create brand awareness and familiarity in India brand has to partner with as many relevant distribution channel partners as possible. We have identified one key element under this dimension that is, ease of access $(\mathrm{Da})$. A brand could argue that it will only focus on selling their products through specific distribution channels as the brand is not comfortable with other available distribution channels. This argument is weak as far as long-term brand sustainability is concerned in addition to limiting the brand's potential value. Under the element ' $\mathrm{Da}$ ' we have identified subelements/items which would be useful in measuring viz., Da1) local retailer's stores (Example Channabasappa \& Sons Davanagere) ; Da2) regional retailer's stores (Example - Kapsons Punjab); Da3) national retailer's stores (Example - Shoppers Stop); Da4) EBO Offline; Da5) EBO Online; Da6) specialty online stores (Example - Myntra), and Da7) generalist online stores (Example - Flipkart).All these sub-elements directly or indirectly help the brand to i) maximize reach $\&$ conversion of any communication efforts; ii) minimize cannibalization \& maximize basket size; iii) utilize the expertise of specialists in each area of demand generation; iv) enable the brand to define specific roles for every demand generating partner; $v$ ) distribute part of the partnering costs as part of brand-level promotional costs to understand the true impact on retail format level profitability; vi) take the brand where the customer is already shopping and ease customer shopping efforts by making it available across existing purchase options for them, and most importantly vii) create brand awareness through Product-Market penetration that is a most economical way of promoting a brand and let customers get familiar with the brand.

Connectors (C): What is most important in achieving the goal of establishing a true lifestyle brand image is how a brand connects supply-side with the demand-side attributes. The internal people, processes, systems, and control measures play an important role in connecting supply and demandsides. Unless all these elements and sub-elements are aligned to the brand's overall personality and image the connection efficiency shall not be up to the expected mark. In case this alignment is weak then it could probably lead to a steady deterioration of the brand's positive image and most importantly it is very difficult to recover this damage in the long run. We have identified one key element under this dimension which is, ease of interaction (Ca).Under the element ' $\mathrm{Ca}$ ' we have identified subelements and items which would be useful in measuring viz., a) brand name awareness created by the brand through consumer's family and friends (Ca1), social activities (Ca2), and digital activities (Ca3); b) brand name familiarity created through consumer's family and friends (Ca4), social activities (Ca5), and digital activities (Ca6); c) ensuring digitally-enabled maps can trace the exact location of a brand in the catchment (Ca7); d) clean and clear store name signages/façade (Ca8), and the store window (Ca9) which indicates the product assortment available in the stores; e) store interiors with clear pathways (Ca10), adequate lighting (Ca11), hygienic washrooms (Ca12), hygienic trial rooms (Ca13), pleasant ambiance (Ca14), neatly displayed merchandise (Ca15), and clear indication regarding product and offer information (Ca16); f) sales personnel who acknowledge every consumer walking into the store (Ca17), well-groomed/presentable (Ca18), empathetic (Ca19), serve both extrinsic and intrinsic needs of consumers (Ca21, Ca22), uses need-based sales pitch (Ca23), honestly convey the available offers (Ca24), empowered to take decisions on real-time basis (Ca25), assists the consumer till the end of transaction (Ca26), shares relevant contact details for any post-sale service requirements (Ca27), thank the consumer for making an effort to visit the store and shop (Ca28), and makes an attempt to request the consumer to refer the store to others; g) transactions which ensure a clear explanation of the bill (Ca29), shares a digital copy of the bill with consumer (Ca30), regularly track and update the order status (Ca31), and ensures on-time delivery of the product ordered (Ca32), and h) grievance redressal system which has empowered help desk team (Ca33) and attempts to resolve all the grievances of consumers on-time (Ca34). All these sub-elements directly or indirectly help the brand to create positive perceptions about the brand for a longer period in consumers' minds. 


\begin{tabular}{|c|c|c|c|c|c|c|c|}
\hline \multirow[b]{2}{*}{ Dimension } & \multirow[b]{2}{*}{ Key Elements } & \multirow{2}{*}{$\begin{array}{l}\text { Item } \\
\text { No. }\end{array}$} & \multirow[b]{2}{*}{ Sub Elements / Measurable Items } & \multicolumn{3}{|c|}{ Existence } & \multirow{2}{*}{$\begin{array}{c}\text { Maximum } \\
\text { Score }\end{array}$} \\
\hline & & & & $\begin{array}{c}\text { No } \\
(\text { Score }=0)\end{array}$ & $\begin{array}{l}\text { Uns ure } \\
\text { (Score = 1) }\end{array}$ & $\begin{array}{c}\text { Yes } \\
(\text { Score }=2)\end{array}$ & \\
\hline \multirow{26}{*}{$\begin{array}{l}\text { Supply } \\
\text { Side } \\
\text { (S) }\end{array}$} & \multirow{14}{*}{$\begin{array}{l}\text { Creating all-in-one } \\
\text { brand image through } \\
\text { wider product offering } \\
\text { catering to multiple } \\
\text { consumer groups } \\
\text { (Sa) }\end{array}$} & Sal & Pregnant Women ; Nursing Women & 0 & 1 & 2 & \multirow{14}{*}{28} \\
\hline & & $\mathrm{Sa} 2$ & Babies & 0 & 1 & 2 & \\
\hline & & $\mathrm{Sa} 3$ & Infants & 0 & 1 & 2 & \\
\hline & & $\mathrm{Sa} 4$ & Kid Boys & 0 & 1 & 2 & \\
\hline & & Sa5 & Kid Girls & 0 & 1 & 2 & \\
\hline & & Sa6 & Teen Boys & 0 & 1 & 2 & \\
\hline & & $\mathrm{Sa} 7$ & Teen Girls & 0 & 1 & 2 & \\
\hline & & Sa8 & Young Women & 0 & 1 & 2 & \\
\hline & & $\mathrm{Sa} 9$ & Young Men & 0 & 1 & 2 & \\
\hline & & $\mathrm{Sa} 10$ & Women & 0 & 1 & 2 & \\
\hline & & Sal1 & Men & 0 & 1 & 2 & \\
\hline & & Sa12 & Apparel & 0 & 1 & 2 & \\
\hline & & Sa13 & Footwear & 0 & 1 & 2 & \\
\hline & & Sa14 & Accessories & 0 & 1 & 2 & \\
\hline & \multirow{12}{*}{$\begin{array}{l}\text { Unique and all-needs- } \\
\text { fulfilment assortment } \\
\text { (Sb) }\end{array}$} & $\mathrm{Sb} 1$ & Essential Products - Displayed Separately & 0 & 1 & 2 & \\
\hline & & $\mathrm{Sb} 2$ & Fashion Products - Displayed Separately & 0 & 1 & 2 & \\
\hline & & $\mathrm{Sb} 3$ & Occasional Products - Displayed Separately & 0 & 1 & 2 & \\
\hline & & $\mathrm{Sb} 4$ & Price Lining - Low & 0 & 1 & 2 & \\
\hline & & $\mathrm{Sb} 5$ & Price Lining - Medium & 0 & 1 & 2 & \\
\hline & & $\mathrm{Sb} 6$ & Price Lining - High & 0 & 1 & 2 & \\
\hline & & $\mathrm{Sb} 7$ & Size Ratio - All Sizes Availability for a Select Design & 0 & 1 & 2 & 24 \\
\hline & & $\mathrm{Sb} 8$ & Size Sets - Inventory Availability for a Select Size and Design & 0 & 1 & 2 & \\
\hline & & $\mathrm{Sb} 9$ & Unique Fits & 0 & 1 & 2 & \\
\hline & & $\mathrm{Sb} 10$ & Unique Silhouettes, Models, and Designs & 0 & 1 & 2 & \\
\hline & & Sb11 & Special Finishes & 0 & 1 & 2 & \\
\hline & & $\mathrm{Sb} 12$ & Unique Packaging & 0 & 1 & 2 & \\
\hline & & $\mathrm{Ca} 1$ & Awareness - Family and Friends & 0 & 1 & 2 & \\
\hline & & $\mathrm{Ca} 2$ & Awareness - Social & 0 & 1 & 2 & \\
\hline & & $\mathrm{Ca} 3$ & Awareness - Digital & 0 & 1 & 2 & \\
\hline & & $\mathrm{Ca} 4$ & Familiarity - Family and Friends & 0 & 1 & 2 & \\
\hline & & $\mathrm{Ca} 5$ & Familiarity - Social & 0 & 1 & 2 & \\
\hline & & $\mathrm{Ca} 6$ & Familiarity - Digital & 0 & 1 & 2 & \\
\hline & & $\mathrm{Ca} 7$ & Locating Brand - Exact Location Traceability in Online Maps & 0 & 1 & 2 & \\
\hline & & $\mathrm{Ca} 8$ & Store Exterior - Clean and Clearly Visible Signage & 0 & 1 & 2 & \\
\hline & & $\mathrm{Ca} 9$ & Store Exterior - Assortment Guiding Windows & 0 & 1 & 2 & \\
\hline & & Ca10 & Store Interior - Clear Path Ways & 0 & 1 & 2 & \\
\hline & & Ca11 & Store Interior - Adequate Lighting & 0 & 1 & 2 & \\
\hline & & Ca12 & Store Interior - Hy gienic Wash Room & 0 & 1 & 2 & \\
\hline & & Ca13 & Store Interior - Hy gienic Trial Room & 0 & 1 & 2 & \\
\hline & & Ca14 & Store Interior - Pleasant Smell, Music, and Temperature & 0 & 1 & 2 & \\
\hline Suppry & & Ca15 & Store Interior - Neatly Displayed Merchandise & 0 & 1 & 2 & \\
\hline & & Ca16 & Store Interior - Clear Indication of Product and Offer Information & 0 & 1 & 2 & \\
\hline Demand & Fase of interaction & Ca17 & Store Manager's Availability in the Store & 0 & 1 & 2 & \\
\hline Demand & Ease or interaction & Ca18 & Sales Personnel - Acknowledging Consumer Walk-In & 0 & 1 & 2 & 70 \\
\hline Side & & Ca19 & Sales Personnel - Grooming and Presentability & 0 & 1 & 2 & \\
\hline Connect & & Ca20 & Sales Personnel - Empathetic & 0 & 1 & 2 & \\
\hline Commect & & Ca21 & Sales Personnel - Served Consumer's Extrinsic Needs & 0 & 1 & 2 & \\
\hline (C) & & Ca22 & Sales Personnel - Served Consumer's Extrinsic and Intrinsic Needs & 0 & 1 & 2 & \\
\hline & & Ca23 & Sales Personnel - Need-Based Sales Pitch & 0 & 1 & 2 & \\
\hline & & Сa24 & Sales Personnel - Conveyed All the Relevant Offers & 0 & 1 & 2 & \\
\hline & & Ca25 & Sales Personnel - Empowered to Take Decisions on Real-Time Basis & 0 & 1 & 2 & \\
\hline & & Ca26 & Sales Personnel - Assisted till the End of Transaction & 0 & 1 & 2 & \\
\hline & & Ca27 & Sales Personnel - Shared Contact Details for Post-Purchase Issues & 0 & 1 & 2 & \\
\hline & & Ca28 & Sales Personnel - Thanked for Shopping & 0 & 1 & 2 & \\
\hline & & Ca29 & Sales Personnel - Requested to Refer the Store to Others & 0 & 1 & 2 & \\
\hline & & Сa30 & Transaction - Bill Details Explained Clearly & 0 & 1 & 2 & \\
\hline & & Ca31 & Transaction - Digital Copy of Bill Sharing & 0 & 1 & 2 & \\
\hline & & Ca32 & Transaction - Order Tracking Shared Regularly & 0 & 1 & 2 & \\
\hline & & Ca33 & Transaction - Received Product On-Time & 0 & 1 & 2 & \\
\hline & & Ca34 & Grievance Redressal - Empowered Help Desk Team & 0 & 1 & 2 & \\
\hline & & Ca35 & Grievance Redressal - On-Time Redressal & 0 & 1 & 2 & \\
\hline & & Dal & Local Retailer's Stores & 0 & 1 & 2 & \\
\hline & & Da2 & Regional Retailer's Stores & 0 & 1 & 2 & \\
\hline Demand & Fase of access & Da3 & National Retailer's Stores & 0 & 1 & 2 & \\
\hline Side & Ease or access & Da4 & EBO Offline Stores & 0 & 1 & 2 & 14 \\
\hline$(\mathbf{D})$ & (Da) & Da5 & EBO Online Store & 0 & 1 & 2 & \\
\hline & & Da6 & Speciality Online Stores & 0 & 1 & 2 & \\
\hline & & Da7 & Generalist Online Stores & 0 & 1 & 2 & \\
\hline
\end{tabular}

Fig. 3: Proposed scale for investors to measure the consumer-level the true potential of lifestyle brands in India: CL-LBSi.

\section{HOW TO USE CL-LBSi INSTRUMENT :}

Once the investors have computed the true potential of a lifestyle brand in India using the FL-LBSi instrument that is a firm-level measurement scale for investors [59], depending upon investors level of interest they can hire mystery shoppers who fall under the target consumer definition of the lifestyle brand being measured and guide them to audit the brand using CL-LBSi instrument which is designed in such a way that it is simpler to use by a consumer. In India, one mystery shopping audit would cost approximately INR 2,500 (Rupees two thousand five hundred only) per mystery shopper and there are 
many organized agencies to conduct such mystery shopping audits. Figure 3 depicts the CL-LBSi scale with scores being allotted to all the 68 sub-elements/items and 3 stages of existence of these subelements when checked by a mystery shopper auditing a particular lifestyle brand on behalf of investors such as i) Non-existent (Score: 0 ); ii) Unsure about the existence Score $=1$ ), and iii) existent (Score = 2). A brand can achieve a maximum overall score equal to 136 which is 100 percent. The recommended methodology of interpretation and decision making for existing and potential investors is illustrated in the form of simple framework number 1 . We were cognizant about the fact that every brand needs a certain time to evolve to a sustainable stage, thus, we have considered the age of a brand in a market as one of the key determinants for making an investment decision in addition to the overall score. This framework could also be used by the investors as milestones to decide on investment stages, frequencies, and magnitude of each investment round.

\begin{tabular}{|c|c|c|c|c|c|c|}
\hline \multirow{2}{*}{\multicolumn{2}{|c|}{$\begin{array}{l}\text { Recommended } \\
\text { Investment } \\
\text { Decision }\end{array}$}} & \multicolumn{5}{|c|}{ Overall Score as Percentage of Total Maximum Score } \\
\hline & & \multirow{2}{*}{$\begin{array}{c}50 \text { to } 59 \% \\
\text { Yes }\end{array}$} & \multirow{2}{*}{$\begin{array}{c}60 \text { to } 69 \% \\
\text { Yes }\end{array}$} & \multirow{2}{*}{$\begin{array}{c}70 \text { to } 79 \% \\
\text { Yes }\end{array}$} & \multirow{2}{*}{$\begin{array}{c}80 \text { to } 89 \% \\
\text { Yes }\end{array}$} & \multirow{2}{*}{$\begin{array}{l}90 \% \& \\
\text { Above } \\
\text { Yes }\end{array}$} \\
\hline B & 0 to 2 Year & & & & & \\
\hline $\mathbf{a}$ & 2 to 5 Years & No & Yes & Yes & Yes & Yes \\
\hline d & 5 to 8 Years & No & No & Yes & Yes & Yes \\
\hline $\mathbf{A}$ & 8 to 10 Years & No & No & No & Yes & Yes \\
\hline e & Above 10 Years & No & No & No & No & Yes \\
\hline
\end{tabular}

Framework 1: Recommended investment decision based on the brand's CL-LBSi overall score and brand age in a particular market

\section{CONCLUSION :}

Through this intensive research work, we have noticed that it is not just about identifying a gap in the market or coming up with a great idea. It is all about understanding the entire market dynamics concerning a lifestyle brand's product assortment and target consumer group, which in India varies by a) City, State, and Region; b) type of supply chain partners; c) type of distribution channel partners and most importantly d) how the brand's personality and the image are communicated to consumers consistently. More than 5000 lifestyle brands of Indian origin in which only a few can be listed as true lifestyle brands indicates that the majority of these brands are not rationally measured by the existing investors and the senior management personnel of the brand organization due to absence of a consumer-level inputs-driven measurement technique/scale/instrument. It is inevitable for brands and investors to evaluate the true potential of a lifestyle brand in India at a micro-level from the consumer point of view and not just based on the revenue a brand has generated and the growth it has recorded. For long-term sustainable profitable lifestyle brand, one has to focus on the 68measurable sub-elements identified in this study which are a subset of 4key elements and 3 dimensions at every stage of the brand's evolution (ideation/strategy stage to sustainable profit stage) which could increase the probability of the brand's success in the long run in addition to enabling the brand to attract investors as and when each milestone are reached.CL-LBSi instrument has been designed considering the majority of sub-elements that are inputs-driven in nature and hence the instrument is a reliable scale to measure the true potential of a lifestyle brand in India by any existing and potential investors before they make an investment decision of any magnitude. 


\section{SUGGESTIONS TO INVESTORS :}

Let us take a look at an example of a typical Indian lifestyle brand organization's attitude. A lifestyle brand organization might believe that their biggest strength is in making Sleep Wear Apparel for MidAged Women, they believe that they understand the category better than competitors. It is not at all wrong in focussing on a specific product line or category, but at the same time what is very important is to ask these brands as to what stops them to extend the offering to few more consumer groups using the same product line or category? On the other hand, a lifestyle brand might believe that their biggest strength is in understanding a specific consumer group for example Kids, they believe that they understand Kid's consumer group better than competitors. It is not at all wrong in focussing on a specific consumer group, but at the same time what stops the brand to extend its product line and categories to cater to the majority of the life-stage needs of your focussed consumer group Kids? Investors who are serious about investing in Indian lifestyle brands need to identify every other investor's and organization's key financial objectives which could have compelled them to have invested in a particular lifestyle brand. The sustainable success of a lifestyle brand significantly depends on the trueness level of a lifestyle brand that is carried in consumers' minds and not the revenue or profit a brand generates. To ensure a brand gets a true lifestyle image in consumers' minds, brands need to think beyond revenue and profit which is what has to be the main criteria while deciding on investing in a lifestyle brand in India. Be cognizant of the fact that, few brands may be trying to capture the bigger market share by just focussing on increasing the revenue; few brands may be trying to show exponential growth in their revenue to attract more investors; few investors may be assuming that consumers acquired by the brand based on discounts and advertising tactics as their key components of selling proposition are going to be loyal to the brand forever in which they have invested; few brands may be trying to create short-term positive perceptions in consumers' mind to impress existing and potential investors, few brands may be opening many EBO stores in premium locations with larger size to tag them as experiential, anchor or destination stores assuming that this effort would lead them to create a premium brand image in investors mind; few brands may be expanding their presence in catchment areas irrespective of their target consumer groups to promote their brand to attract new investors; few conglomerates may be trying to show their presence in the lifestyle retailing segment to enhance their overall group portfolio and hence investing in few lifestyle brands; few may be selling premium priced products or categories to position themselves as premium lifestyle brands; and few renowned angel investors might have invested in a lifestyle brand owing to past academic and industrial affiliations of founders and so on. What is very important is the understanding of Indian retailing dynamics and the brand's short-term and long-term plans which must be aligned to the final goal of attaining a sustained profitable stage in addition to gaining true lifestyle images in existing and potential employees, investors, competitors, and consumers' mind. Finally, we would like to suggest investors interested in investing in lifestyle brands in India to apply an unbiased empirical approach while making an investment decision and we strongly believe that the CL-LBSi instrument would help investors to adopt the suggested approach. In addition to using the CL-LBSi instrument to make investment decisions, we recommend they also insist the brand organizations to use the scale to regularly monitor the brand's performance form consumers point of view.

\section{LIMITATIONS OF RESEARCH :}

The main limitation of this research work is the coverage of various stakeholders viz., number and type of investors, number of lifestyle brands, product categories, consumer groups, employees, price positioning, product mix, category mix, and different types of Marketing Mix in designing the CLLBSi instrument. This might limit the generalizability of the research findings to other sets of lifestyle brands. The second limitation would be the empirical validation is restricted to a few Indian lifestyle brands selected for the study and hence the generalizability of the findings and suggestions to other Indian lifestyle brands. The third limitation would be our ability to identify inputs based on subelements while designing the instrument, we could have missed a few. However, as the proposed scale has been based on, i) proven theories in the field of marketing; ii) based on exhaustive empirical research The findings of this study; iii) based on inputs-driven measures, and iv) based on recommendations from our previous experimental and empirical research studies which are relevant to 
this context [60 to 71], it would be instrumental in accurately gauging, estimating and forecasting the true potential of a lifestyle brand in India.

\section{SCOPE FOR FURTHER RESEARCH :}

We strongly recommended that the CL-LBSi instrument is used by researchers to further test its validity and reliability in addition to finetuning it further if required for Indian lifestyle or non-lifestyle brands. Based on the key business objectives of investors and lifestyle brands, the CL-LBSi instrument can be used as a basic tool to measure the brand's true potential in addition to adding few other sub-elements which are crucial for them and are not part of the scale proposed.

\section{REFERENCES :}

[1] Schmitt, B. (2012). The consumer psychology of brands. Journal of Consumer Psychology. 22 (1), 7-17.

[2] http://www.technopak.com/Files/fashion-retail-scenario-in-india.pdf. Retrieved in June 2020.

[3] http://statisticstimes.com/demographics/population-of-india.php. Retrieved in June 2020.

[4] https://www.mckinsey.com/industries/retail/our-insights/the-state-of-fashion-2019-a-year-ofawakening. Retrieved in June 2020.

[5] https://www.amazon.in/b/?ie=UTF8\&node $=6648217031 \&$ ref $=$ topnav storetab top ap mega. Retrieved in June 2020.

[6] Biel, A. (1993). Converting image into equity. In Brand Equity and Advertising, Aaker, D. and Biel, A. (eds), Lawrence Erlbaum Associates, Hillsdale, NJ, 67-82.

[7] Michel Laroche and Robert Sadokierski (1994). Role of confidence in a multi-brand model of intentions for a high-involvement service. Journal of Business Research, 29(1), 1-12.

[8] Keller, K. L. (1993). Conceptualizing, measuring, and managing customer-based brand equity. Journal of Marketing, 57, 1-22. Lutman, M. R. (1991). End-benefit segmentation and prototypical bonding. Journal of Advertising Research, 31(3), 9-18.

[9] Badenhausen, K. (1996, July 8). Blind faith. Financial World, 50-55.

[10] Aaker, D. A. (1991). Managing brand equity. New York: Free Press.

[11] Starčević, S. (2013) Istraživanje koncepta ličnosti brenda u marketingu. Marketing, 44(2), 149172.

[12] Fournier, S. (1998) Consumers and their brands: Developing relationship theory in consumer research. Journal of Consumer Research,24(4), 343-373.

[13] Sethuraman, Raj. (2001). What Makes Consumers Pay More for National Brands than for Store Brands - Image or Quality? Review of Marketing Science. WP No. 318, 24-28.

[14] Dignam, Conor. (1999). The beginning of a profitable friendship. Marketing Sept 30. Retrieved in June 2020.

[15] McCracken, G. (1989). Who is the celebrity endorser? Cultural foundations of the endorsement process. Journal of Consumer Research, 16, 310-21.

[16] Parasuraman, A., Zeithaml, V.A., Berry, L.L. (1994). Reassessment of expectations as a comparison standard in measuring service quality: implications for future research. Journal of Marketing, 58 (1), 111-124.

[17] Simon, C.J. and Sullivan, M.J. (1993). The Measurement and Determinants of Brand Equity: A Financial Approach. Marketing Science, 12, 28-52.

[18] Hayes, J. B., Alford, B. L., Silver, L., \& York, R. P. (2006). Looks matter in developing consumerbrand relationships. The Journal of Product and Brand Management, 15(5), 306. 
[19] Lev, B. (2004). Sharpening the intangibles edge. Harvard business review, 6, 109-116.

[20] Füller, J., Matzler, K., \& Hoppe, M. (2008). Brand community members as a source of innovation. Journal of Product Innovation Management, 25(6), 608-619.

[21] Da Silva, R. V., \& Alwi, S. F. S. (2006). Cognitive, affective attributes and conative, behavioural responses in retail corporate branding. Journal of Product \& Brand Management, 15(5), 293-305.

[22] Roncha, A. (2008). Nordic brands towards a design-oriented concept. Journal of Brand Management, 16(1-2), 21-29.

[23] Craig, J. B., Dibrell, C., \& Davis, P. S. (2008). Leveraging family-based brand identity to enhance the firm competitiveness and performance in family businesses. Journal of Small Business Management, 46(3), 351-371.

[24] Jun, J. W., Cho, C. H., \& Kwon, H. J. (2008). The role of affect and cognition in consumer evaluations of corporate visual identity: Perspectives from the United States and Korea. Journal of brand management, 15(6), 382-398.

[25] Smith, T. (2007). The essential consumption paradox: an exploration of meaning in marketing. The Marketing Review, 7(4), 325-341.

[26] Sargeant, A., Hudson, J., \& West, D. C. (2008). Conceptualizing brand values in the charity sector: the relationship between sector, cause, and organization. The Service Industries Journal, 28(5), 615632.

[27] Westbrook, R. A., \& Newman, J. W. (1978). An analysis of shopper dissatisfaction for major household appliances. Journal of Marketing research, 15(3), 456-466.

[28] Batra, R., Lehmann, D. R., \& Dipinder S. (1993). The brand personality component of brand goodwill: some antecedents and consequences, in Brand Equity and Advertising, David A. Aaker and Alexander Biel, eds. Hillsdale, NJ: Lawrence Erlbaum Associates, 83-96.

[29] Punj, G. N. and Hillyer, C. L. (2004). A cognitive model of customer-based brand equity for frequently purchased products: conceptual framework and empirical results. Journal of Consumer Psychology, 14(1/2), 124-131.

[30] Biel, L. B. (1997). Discovering brand magic: the hardness of the softer side of Branding. International Journal of Advertising, 16, 199-210.

[31] de Chernatony, L. \& McDonald, M. (1998). Creating powerful brands in consumer, service, and industrial markets. $2^{\text {nd }}$ edition Oxford, Butterworth Heinemann, London, 38-92.

[32] Keller, K.L. (2003). Brand synthesis: the multidimensionality of brand knowledge. Journal of Consumer Research, 29, 595-600.

[33] Feldwick, P. (1996). What is brand equity anyway, and how do you measure it? Journal of the Market Research Society, 38, 85-104.

[34] Lane, V., \& Jacobson, R. (1995). Stock market reactions to brand extension announcements: The effects of brand attitude and familiarity. Journal of Marketing, 59(1), 63-77.

[35] Berry, L. L. (2000). Cultivating service brand equity. Journal of the Academy of Marketing Science, 28(1), 128-38.

[36] Atilgan, E., Aksoy, S. and Akinci, S. (2005). Determinants of the brand equity. A verification approach in the beverage industry in Turkey. Marketing Intelligence and Planning, 23(3), 237-248.

[37] Mishra, Pallabi., \& Datta, Biplab. (2011). Perpetual Asset Management of Customer-Based Brand Equity - The PAM Evaluator, India. Journal of Social Sciences, 3(1), 34-43.

[38] McAlexander, James H., John W. Schouten, and Harold F. Koenig. (2002). Building Brand Community. Journal of Marketing, 66 (1), 38-54. 
[39] Thomson, Matthew, Deborah J. MacInnis., \& C. Whan Park. (2005). The Ties That Bind: Measuring the Strength of Consumers' Emotional Attachments to Brands. Journal of Consumer Psychology, 15(1), 77-91.

[40] Carroll, Barbara A., \& Aaron, Ahuvia. (2006). Some Antecedents and Outcomes of Brand Love. Marketing Letters, 17(2), 79-89.

[41] Schmitt, B. H. (2000). Experimental Marketing: How to get Customers to Sense, Feel, Think, Act and Relate to Your Company and Brands. European Management Journal, 18(6), 695.

[42] Hoch, Stephen J. (2002). Product Experience Is Seductive. Journal of Consumer Research, 29 (December), 448-454.

[43] Roger A, Kerin., Jain, Ambuj., \& Howard. J. Daniel (1992). Store Shopping Experience and Consumer Price-Quality-Value Perceptions. Journal of Retailing, 68(4), 376-97.

[44] Michael K, Hui., \& Bateson E.G. John (1991). Perceived Control and the Effects of Crowding and Consumer Choice on the Service Experience. Journal of Consumer Research, 18 (September), 17484.

[45] Moris, B. Holbrook., \& Hirschman, C. Elizabeth (1982). The Experiential Aspects of Consumption: Consumer Fantasies, Feelings, and Fun. Journal of Consumer Research, 9 (9), 132-40.

[46] Esch, F.R. (2007). Strategie und Technik der Markenführung. (5th Edition). Vahlen: Stuttgart, pp. 26-49.

[47] Schaefer, A. (1997). Consumer knowledge and country of origin effects. European Journal of Marketing, 31(1), 56-72.

[48] Brown, Stephen, Robert V. Kozinets, and John F. Sherry Jr. (2003). Teaching Old Brands New Tricks: Retro Branding and the Revival of Brand Meaning. Journal of Marketing, 67(3), 19-33.

[49] Blackett, T. (1989). The role of brand valuation in marketing strategy. Marketing and Research Today, 17(11). 245-248.

[50] Murphy, J. (1989). Good brand husbandry techniques. In J. Murphy (ed.), Brand valuation: Establishing a true and fair view. London: The Interbrand Group, 59-93.

[51] Tauber, Edward, M. (1981). Brand Franchise Extension: New Product Benefits from Existing Brand Names. Business Horizons, 24, 36-41.

[52] Aaker, D. A., \& Keller, K. L. (1990). Consumer evaluations of brand extensions. Journal of marketing, 54(1), 27-41.

[53] Diehl K., Zauberman G., \& Barasch A. (2016). How taking photos increases enjoyment of experiences. Journal of Personality and Social Psychology, 111(2), 119-140.

[54] https://www2.deloitte.com/content/dam/Deloitte/in/Documents/consumer-business/in-consumerRLS-2019-noexp.pdf. Retrieved in June 2020.

[55] Lavidge, R. J. and Steiner, G.A., (1961). A Model for Predictive Measures of Advertising Effectiveness, Journal of Marketing, October, 59-62.

[56] McCarthy, E. J. (1960). Basic marketing: a managerial approach. Homewood, Illinois: Richard D. Irwin. Inc. McCarthy Basic Marketing: A Managerial Approach, 1960, pp 24-95.

[57] Ganesha, H. R. \& Aithal, P. S. (2020). Establishing True Lifestyle Brand in India: An Integrated Marketing Mix Framework. International Journal of Management, Technology, and Social Sciences (IJMTS), 5(1), 261-284.

[58] Ganesha, H. R. \& Aithal, P. S. (2020). Rational Distribution Channel Mix for Lifestyle Brands in India - An Empirical Study. International Journal of Case Studies in Business, IT, and Education (IJCSBE),4(1), 136-154. 
[59] Ganesha, H. R. \& Aithal, P. S. (2020). Measuring True Potential of Lifestyle Brands in India: A Firm-Level Scale for Existing and Potential Investors (FL-LBSi). International Journal of Applied Engineering and Management Letters (IJAEML), 4(1), 279-302.

[60] Ganesha, H. R., Aithal, P. S. \& Kirubadevi, P. (2020). Consumer Affordability in Tier-1, Tier-2 and Tier-3 Cities of India - An Empirical Study. International Journal of Applied Engineering and Management Letters (IJAEML), 4(1), 156-171.

[61] Ganesha, H. R., Aithal, P. S. \& Kirubadevi, P. (2020). Ideal Store Locations for Indian Retailers - An Empirical Study. International Journal of Management, Technology, and Social Sciences (IJMTS), 5(1), 215-226.

[62] Ganesha, H. R., Aithal, P. S., \& Kirubadevi, P. (2020). Inputs and Output Driven Sales Personnel Performance Measures: Insights from an Experiment. International Journal of Case Studies in Business, IT, and Education (IJCSBE),4(1), 23-37.

[63] Ganesha, H. R., Aithal, P. S., \& Kirubadevi, P. (2020). Integrated Inventory Management Control Framework. International Journal of Management, Technology, and Social Sciences (IJMTS), 5(1), 147-157.

[64] Ganesha, H. R., Aithal, P. S. \& Kirubadevi, P. (2020). Optimal Category Mix in Multi-Category Retailing - Insights from an Experiment. International Journal of Case Studies in Business, IT, and Education (IJCSBE), 4(1), 112-126.

[65] Ganesha, H. R., Aithal, P. S., \& Kirubadevi, P. (2020). Changes in Consumer Perspective towards Discount at Brick-and-Mortar Stores owing to Emergence of Online Store Format in India. International Journal of Management, Technology, and Social Sciences (IJMTS), 5(1), 43-83.

[66] Ganesha, H. R., Aithal, P. S., \& Kirubadevi, P. (2020). Short-Term Discounting Frameworks: Insights from Multiple Experiments. International Journal of Case Studies in Business, IT, and Education (IJCSBE), 4(1), 8-22.

[67] Ganesha, H. R., Aithal, P. S., \& Kirubadevi, P. (2020). Long-Term Discounting Frameworks: Insights from Multiple Experiments. International Journal of Management, Technology, and Social Sciences (IJMTS), 5(1), 84-100.

[68] Ganesha, H. R., Aithal, P. S., \& Kirubadevi, P. (2020). Decentralized Discounting Framework: Insights from an Experiment. International Journal of Applied Engineering and Management Letters (IJAEML), 4(1), 20-40.

[69] Ganesha, H. R., Aithal, P. S. \& Kirubadevi, P. (2020). Integrated Discounting Framework for Indian Brick-and-Mortar Retailers. International Journal of Management, Technology, and Social Sciences (IJMTS), 5(1), 110-123.

[70] Ganesha, H. R., Aithal, P. S. \& Kirubadevi, P. (2020). Impact of Store Size Reduction on Overall Store Performance - Insights from an Experiment. International Journal of Case Studies in Business, IT, and Education (IJCSBE), 4(1), 103-111.

[71] Ganesha, H. R., Aithal, P. S. \& Kirubadevi, P. (2020). Integrated Marketing Mix Framework for Baby Care Retailing in India. International Journal of Applied Engineering and Management Letters (IJAEML),4(1), 191-219.

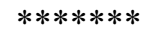

